\title{
永久磁石の放電加エにおける加工雾囲気の影響
}

\section{Influence of Machining Environment on Permanent Magnet by EDM}

\author{
武沢英樹 - 工学院大学 \\ Hideki Takezawa, Kogakuin University
}

\author{
横手暢弘・工学院大学 \\ Nobuhiro Yokote, Kogakuin University
}

\author{
毛利尚武・大学評価・学位授与機構 \\ Naotake Mohri, National Institution for \\ Academic Degrees and University Evaluation
}

During EDM of the permanent magnet, a second magnet for the external magnetic field was set up, and the internal temperature and surface magnetic flux density on the opposite surface of the permanent magnet during machining were evaluated. It was found that even though the internal temperature of the magnet remained unchanged, the surface magnetic flux density changed when the external magnetic field was varied. In addition, the magnetic field generated by the magnet changed when a plate with high permeability was pressed onto the surface of the permanent magnet.

\section{Key Words: EDM, Permanent Magnet, Surface Magnetic Flux Density, Magnetic field}

\section{1. 緒 言}

筆者らはこれまで, 硬脆材料であり磁力を有することから 加工が難しいネオジム磁石の熱エネルギ加工について研究 を進めてきた ${ }^{1)}{ }^{2}$ ). ネオジム磁石は，磁力を消失する $320^{\circ} \mathrm{C}$ 程度のキュリー点を有する．また，着磁後に形状が変化する と, それに依存して表面磁束密度分布が変化する. そこで, 着磁後のネオジム磁石の形状と磁束密度分布を同時に，ある いは個別に制御することを目的に研究を進めてきた。これま でに, 円筒形磁石の磁石高さを低減する突き当て加工では, 放電条件によって磁石の内部温度が変化し, 磁石内部温度に 依存して, 加工面の磁力低下が生じる. また, 角形磁石の中 央に底付き穴加工を行うと，穴対向面の中央部が転極する現 象があることがわかっている.

本研究では, 角形ネオジム磁石の底付き穴加工において, 加工磁石の周りに発生する磁場状態に変化を与えた影響に ついて調べた.

\section{2. 通常の磁場雾囲気での底付き穴加工}

はじめに, 加工磁石自身による磁場雾囲気中で角形ネオジ ム磁石の中心に底付き穴加工を行い, 各穴深さの加工穴対向 面の磁束密度変化を測定した. 実験に用いたネオジム磁石は (Nd-42, 推奨使用温度 $80^{\circ} \mathrm{C}$ 以下, 初期表面磁束密度 $360 \mathrm{mT}$ ) であり， $10 \times 10 \times 5 \mathrm{~mm}$ の角形である. 形彫放電加工機（ソ ディック製 $\mathrm{AM} 3 \mathrm{~L}$ ）を用いて，直径 $3 \mathrm{~mm}$ の銅電極を正極性 とし, $\mathrm{N}$ 極面の中心から穴深さ $2.5 \mathrm{~mm}, 3.5 \mathrm{~mm}, 4.5 \mathrm{~mm}$ の 3 種類の加工を行った. 電流值 $5 \mathrm{~A}$, On-Off time $32 \mu \mathrm{s}$, D.F. $50 \%$ の放電条件を使用し, 磁束密度の測定は加工後磁石が常温に 戻った後に, 加工穴対向面中心部にテスラメータのホール素 子を密着させて計測した. その結果, 図 1 中それぞれの左棒

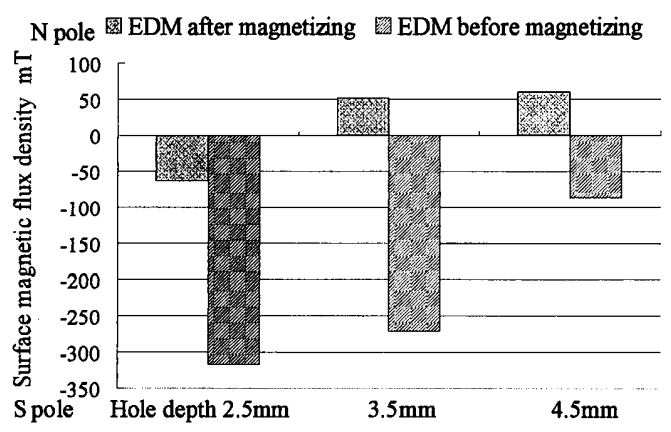

Fig.1 Change in the magnetic flux density due to EDM before and after magnetization as a function of the hole depth の值で示されるように，2.5m m穴深さでは約 $60 \mathrm{mT}[\mathrm{S}$ 極], 穴深さ $3.5 \mathrm{~mm}$ 及び $4.5 \mathrm{~mm}$ では転極現象が発生し約 $50 \mathrm{mT}[\mathrm{N}$ 極]となった. 穴深さの違いにより急激な磁束密度低下や転 極現象が起きた理由として, 放電加工による内部温度上昇や 底付き穴形状変化による影響では無いかと推察した。

そこで, (1)形状変化に伴う磁束密度変化, (2)加工中の内部 温度変化に伴う磁束密度変化の2 種類の影響を確かめるため に, 次のような実験を行った。 一つめ(1)は, 同形状の磁石を 異なる着磁タイミングで製作し，表面磁束密度を比較した。 具体的には最終着磁前の角形ネオジム磁石に対して, 底付き 加工を行い，その穴加工後に着磁を行ったサンプルを作成し， 着磁磁石の加工サンプルと比較した. 穴加工後に着磁された サンプルは, 加工後に一軸方向に着磁されたため, 形状にの み依存する磁力を持つ磁石となる. 図 1 に両者をまとめて示 す. 加工後着磁した磁石の穴対向面では転極現象は発生せず, $2.5 \mathrm{~mm}$ 穴樑さで約 $320 \mathrm{mT}[\mathrm{S}$ 極], $3.5 \mathrm{~mm}$ 穴哚さで約 $270 \mathrm{mT}[\mathrm{S}$ 極], $4.5 \mathrm{~mm}$ 穴深さで約 $80 \mathrm{mT}[\mathrm{S}$ 極]といずれも $\mathrm{S}$ 極のままで あった. 穴深さが増すに従い磁束密度は減少するが，転極に は至らない。これより, 加工中に随時変化する磁石形状に依 存して磁石自身から発生する磁場に変化が生じ, 加工後の表 面磁束密度に影響を与えていることが考えられる。

二つめ(2)の実験では, 着磁磁石の穴深さ $2.5 \mathrm{~mm}$ 放電加工 中の磁石内部温度の測定を行った. 先端約 $0.5 \mathrm{~mm} の \mathrm{~K}$ 熱電 対を用いて, 図加工面上面 $[\mathrm{N}$ 極]より $3.5 \mathrm{~mm}$ 下の中心位置で 計測した.この条件では, 計測部位の磁石内部温度は加工開

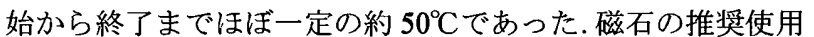
温度が約 $80^{\circ} \mathrm{C}$ であることを考慮すると, 磁石内部の温度上昇 による磁束密度の低下は小さいと考えられる. ただし, 加工 後の穴対向面の磁束密度は $360 \mathrm{mT}$ から $60 \mathrm{mT}$ 一と大幅に減 少する.これより, 加工穴深さの違いによる磁束密度の低下 や転極現象の発生は, 磁石形状が変化することの影響が大き く, これは, 磁石形状に依存して磁石から発生する磁場が変 化していることが影響しているのではないかと推察するに いたった.

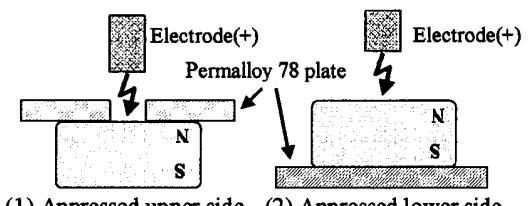

(1) Appressed upper side (2) Appressed lower side

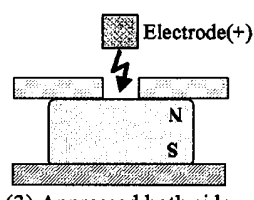

(3) Appressed both side
Fig.2 Schematic diagram of the experimental set up 


\section{3. 外部磁場雾囲気を変化させた底付き穴加工}

次に, 磁石の形状加工においては, 加工中の磁石周囲の磁 場状態の変化が, 加工後の磁束密度変化に影響を与えている ことが推察されたことから, 積極的に磁石周囲の磁場状態を 変化させて, 底付き穴加工を行った．穴加工中の加工磁石周 囲の磁場を変化させるために，磁気シールドや磁気遮断で利 用される 78-パーマロイ板(ニコラ製)を用いた。板サイズは $50 \times 50 \times 2 \mathrm{~mm}$ であり，図 2 の様に 3 種類の設置方法で比較 した．同図-(a)(c)の場合は, 上面の板中央部に直径 $3.5 \mathrm{~mm}$ の 穴をあけ, 直径 $3 \mathrm{~mm}$ の電極が通過できるようにしてある. 加工中の内部温度計測は前節と同様にして行った. 加工後の 磁束密度の測定では、磁石が常温に戻った後にパーマロイ板 を取り外して測定を行った。

それぞれ加工中の内部温度計測の結果を図 3 に示す. パー マロイ板の有無及び設置面の違いによって内部温度の差は なく, パーマロイ板を設置しない場合と同様に, 加工面 $1 \mathrm{~mm}$ 下で約 $50^{\circ} \mathrm{C}$ となった. これより, 加工中の外部磁場が変化し ても, 磁石内部温度に変化はなく, 磁石内部温度は加工条件 に依存することがわかる。

図 4 に，加工穴深さ $2.5 \mathrm{~mm}$ におりる 3 種類のパーマロイ 板設置と無設置の場合の, 加工後の穴対向面の磁束密度変化 を示す．パーマロイ板を設置すれば， 3 種類の方法で磁束密 度の值は異なるが, いずれの場合も磁束密度の低下が小さく なることがわかる. 上面に設置した場合では，加工前と比心゙ て約 52\%減少し $170 \mathrm{mT}$ [S 極], 下面・上下面に設置した場合 ではほぼ同等であり約 $22 \%$ 減少し $270 \sim 280 \mathrm{mT}[\mathrm{S}$ 極]となっ た.いずれも磁石単体で加工した場合と比較して磁束密度の 低下は小さくなっている. いずれの場合も, 加工中の磁石内 部温度はほぼ $50^{\circ} \mathrm{C}$ 程度と同様であることから, 加工後の磁束 密度の違いは, 加工中の磁石外周部に生じる磁場の違いが影 響していると推察できる。

パーマロイ板を各設置面においた時の加工磁石自身から 発生する磁場を定常による解析行った.解析ソフト COMSOL Multiphysics を用いて, 加工前の初期状態のみの比較をした.
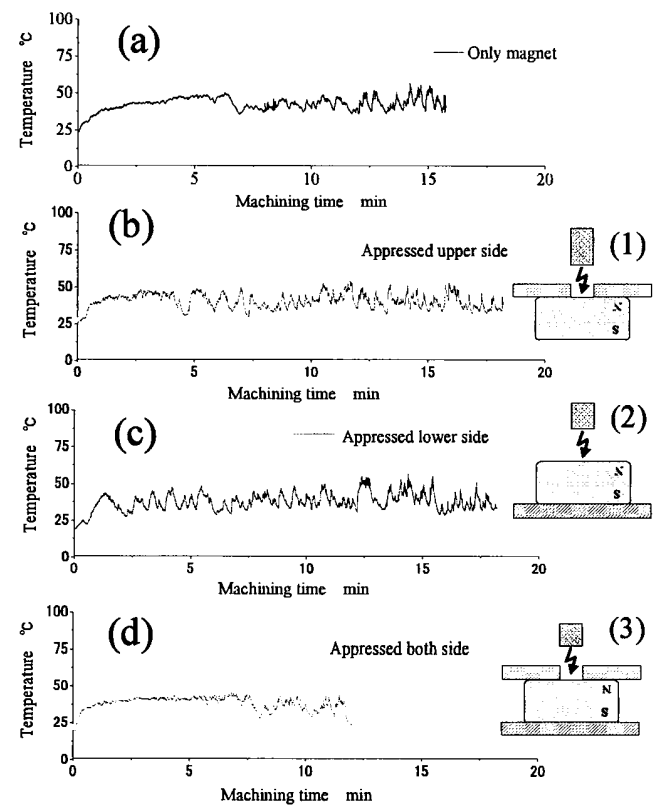

Fig.3 Change in the internal temperature during EDM with appressed Permalloy 78 plates
図 5 に各パーマロイ密着面時の磁石断面を磁力線として示 す．同図(1)のパーマロイ板を上面に設置した場合では，磁石 から発せられた磁場はパーマロイ内部を通って外側に発散 し, 磁石上面に出る磁力線は非常に少ない. 同図(2)のパーマ ロイ板を下面に設置した場合では， N 極から発せられる磁場 は空間を通り，パーマロイ板内部を通って $\mathrm{S}$ 極に戻る。この 時 $\mathrm{S}$ 極に戻る磁場はパーマロイ内部で集約されている. 同図 (3)では, N 極から発せられた磁場は上面のパーマロイ内部を 通って磁石外側に発散され，発散された磁場は下面のパーマ ロイ内部を通って集約され S 極に戻る. 加工前の磁石から発 せられる磁場状態を見ても違いがある為, 加工後の磁束密度 変化の違いはパーマロイ密着による加工中の磁場変化だと 推察できる.

\section{4. 結 言}

角形ネオジム磁石の中央に，同一加工条件にて底付き穴加 工を行う際，加工中の磁石外周部の磁場を変化させた．その 結果, 加工後の穴対向面の磁束密度に違いが見られ, 以下の 内容が明らかとなった。

(1) 同一加工深さの穴加工でも，パーマロイ板の設置方法 により, 加工後の穴対向面の表面磁束密度に違いが生じる. 加工中の磁石内部温度はいずれの場合も同一であるため, パ 一マロイの設置方法による影響と考えられる.

(2) 加工磁石にパーマロイを密着させた時の，定常磁場解 析を行った結果, それぞれの設置方法で磁場の状態が変わる ことがわかる.これら，加工磁石の外周部に発生する磁場状 態の違いが磁束密度変化に影響していると考えられる.

<参考文献 $>$

(1) Hideki TAKEZAWA et al., Relationship between Thermal Influence and Magnetic Characteristics in Electrical Discharge Machining of Magnetic Materials, Key Engineering Materials Vol. 516 (2012) pp.575-579.

(2) Yoshihiro ICHIMURA et al., Relationship between Magnetic Flux Density and Temperature Distributions of Permanent Magnets by EDM, Key Engineering Materials Vol. 523-524 (2012) pp.322-327.

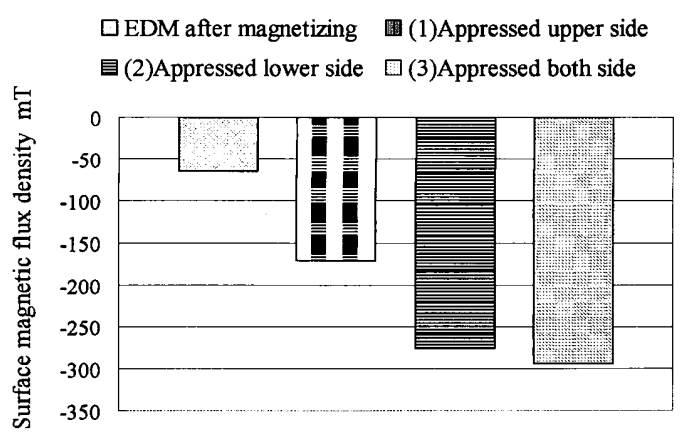

Fig.4 Magnetic flux density as a function of the appressed type
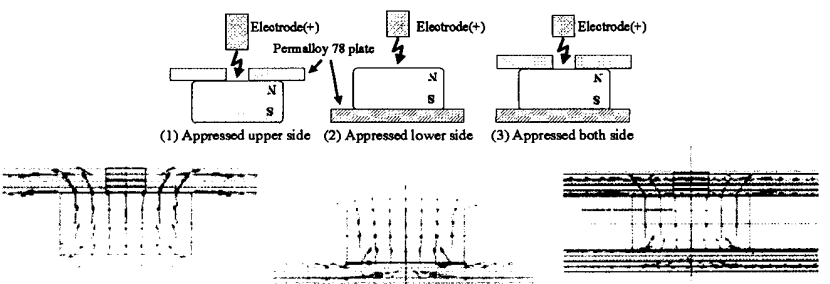

Fig.5 Static magnetic field analysis results 